\title{
CORRECTION
}

\section{Genetic Risk Scores and Hallucinations in Parkinson Disease}

\section{Patients}

Neurol Genet 2021;7:e545. doi:10.1212/NXG.0000000000000545

In the article "Genetic risk scores and hallucinations in Parkinson disease patients" by Kusters et al., ${ }^{1}$ Lars Bertram should be listed as Lars Bertram, MD, in the byline and Author Disclosures section. The authors regret the error.

\section{Reference}

1. Kusters CDJ, Paul KC, Duarte Folle A, et al. Genetic risk scores and hallucinations in Parkinson disease patients. Neurol Genet 2020;6: e492. doi: 10.1212/NXG.0000000000000492. 


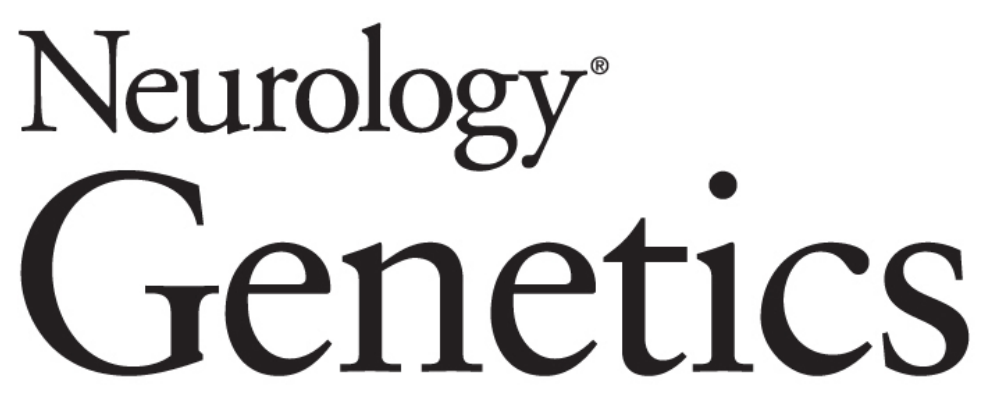

\section{Genetic Risk Scores and Hallucinations in Parkinson Disease Patients \\ Neurol Genet 2021;7; \\ DOI 10.1212/NXG.0000000000000545}

This information is current as of December 21, 2020

\section{Updated Information \&} Services

References

Permissions \& Licensing

Reprints including high resolution figures, can be found at: http://ng.neurology.org/content/7/1/e545.full.html

This article cites 1 articles, 1 of which you can access for free at: http://ng.neurology.org/content/7/1/e545.full.html\#\#ref-list-1

Information about reproducing this article in parts (figures,tables) or in its entirety can be found online at:

http://ng.neurology.org/misc/about.xhtml\#permissions

Information about ordering reprints can be found online: http://ng.neurology.org/misc/addir.xhtml\#reprintsus

Neurol Genet is an official journal of the American Academy of Neurology. Published since April 2015, it is an open-access, online-only, continuous publication journal. Copyright @ 2020 American Academy of Neurology. All rights reserved. Online ISSN: 2376-7839.

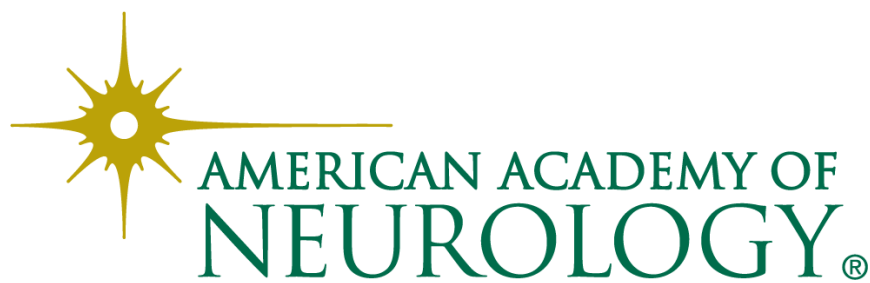

